\title{
ANALISIS PENGELOLAAN LIMBAH MEDIS PADAT PADA FASILITAS KESEHATAN TINGKAT PERTAMA KOTA PADANG
}

\author{
Rahma Nella*, Fuji Astuti Febria, Mahdi \\ Program Pascasarjana Teknik Lingkungan Universitas Andalas, Padang, Indonesia \\ e-mail: nella_rahma@ymail.com
}

\begin{abstract}
Abstrak
Pengelolaan limbah medis padat merupakan tahapan dimulai dari pemilahan hingga pemusnahan. Pada pelaksanaan pengelolaan limbah medis padat masih ditemukan beberapa tahapan yang belum sesuai dengan kebijakan seperti penggunaan kantong plastik belum sesuai dengan jenis dan karakteristik limbah, penggunaan desinfeksi terhadap wadah limbah medis yang telah digunakan, masih minimnya penggunaan Alat Pelindung Diri. Disamping itu pengetahuan dan sikap petugas pengelola limbah medis masih rendah, sehingga diperlukan dukungan pimpinan. Tujuan penelitian ini adalah menganalisis pengelolaan limbah medis padat dan mengetahui pengaruh tingkat pengetahuan, sikap dan dukungan pimpinan terhadap pengelolaan limbah medis padat di Fasilitas Pelayanan Kesehatan Tingkat Pertama (FKTP) Kota Padang. Penelitian ini menggunakan metode deskriptif kuantitatif dengan sampel sebesar 58 sampel dengan analisis Regresi Berganda. Untuk FKTP sebagian besar telah melaksanakan pengelolaan limbah medis sesuai dengan peraturan yang telah. Hasil regresi berganda bahwa pengetahuan, sikap dan dukungan pimpinan berpengaruh nyata terhadap pengelolaan limbah medis padat. Untuk FKTP seperti Puskesmas dan Klinik sudah melaksanakan pengelolaan limbah medis sesuai standar yang ditetapkan namun untuk praktek dokter gigi masih rendah dalam penerapan peraturan pengelolaan limbah medis padat. Diharapkan untuk seluruh FKTP mempunyai komitmen dalam pengelolaan limbah medis padat serta adanya konstribusi dari Dinas Lingkungan Hidup, Dinas Kesehatan, Manajemen dari FKTP serta stake holder lainnya.
\end{abstract}

Kata Kunci: Pengelolaan limbah medis, FKTP, pengetahuan, sikap, dukungan pimpinan

\begin{abstract}
Solid medical waste management is a stage starting from sorting to destruction. In the implementation of solid medical waste management, several stages were found that were not following the policy. The purpose of this study was to analyze the management of solid medical waste and determine the effect of the level of knowledge, attitude and leadership support on the management of solid medical waste in the First Level Health Service Facility (FKTP) Padang City. This study uses a quantitative descriptive method with a sample of 58 samples with multiple regression analysis. Most of the FKTP have implemented medical waste management following existing regulations. Multiple regression results show that knowledge, attitudes and leadership support have a significant effect on solid medical waste management. For FKTPs such as Puskesmas and Clinics, they have implemented medical waste management according to the standards set, but for dentistry, the implementation of solid medical waste management regulations is still low. It is hoped that all FKTPs commit to solid medical waste management as well as contributions from the Environment Service, Health Service, Management from FKTP and other stakeholders.
\end{abstract}

Keywords: Medical waste management, FKTP, knowledge, attitude, leadership support 


\section{PENDAHULUAN}

Penyelenggaraan pelayanan di fasilitas pelayanan kesehatan harus memberikan kondisi lingkungan yang baik agar fungsi fasilitas pelayanan kesehatan dapat berjalan dengan aman dan lancar. Namun tantangan bagi fasilitas pelayanan kesehatan adalah limbah atau hasil sampingan dari kegiatan akan berdampak negatif pada keduanya yaitu kesehatan dan lingkungan yang secara langsung atau tidak langsung, juga akan mengarah pada kesehatan masyarakat. Salah satu dampak dari kegiatan pelayanan kesehatan di fasilitas kesehatan adalah menghasilkan limbah Bahan Berbahaya dan Beracun (B3) atau limbah medis. Setiap orang atau usaha yang menghasilkan limbah B3 wajib melakukan pengelolaan limbah B3 yang dihasilkannya (UndangUndang Nomor 32 Tahun 2009).

Peraturan Menteri Lingkungan Hidup dan Kehutanan No 56 Tahun 2015 yang termasuk dalam Fasilitas Pelayanan Kesehatan adalah Pusat Kesehatan Masyarakat, Klinik Pelayanan Kesehatan atau Sejenis dan Rumah Sakit. Berdasarkan Peraturan Pemerintah Republik Indonesia No 47 Tahun 2016 mengenai Fasilitas pelayanan kesehatan memiliki tingkat pelayanan yaitu fasilitas pelayanan kesehatan tingkat pertama melayani dan melaksanakan pelayanan kesehatan dasar yang terdiri dari praktek dokter mandiri, klinik dan sejenisnya, serta puskesmas, fasilitas pelayanan kesehatan tingkat kedua melayani dan melaksanakan pelayanan kesehatan dasar dan spesialistik terdiri dari Rumah Sakit tipe C dan B, sedangkan fasilitas pelayanan tingkat ketiga melayani dan melaksanakan pelayanan kesehatan dasar, spesialistik dan sub spesialistik terdiri dari Rumah Sakit tipe A (Peraturan Menteri Lingkungan Hidup No 56 Tahun 2015) (Peraturan Pemerintah Nomor 47 Tahun 2016).

Fasilitas Pelayanan Kesehatan Tingkat Pertama (FKTP) merupakan pelayanan kesehatan tingkat dasar yang dilakukan oleh tenaga medis yaitu dokter atau dokter gigi. Dalam pelaksanaan pelayanan kesehatan FKTP tidak hanya menghasilkan limbah domestik namun juga limbah B3. Limbah B3 atau limbah medis di FKTP terdiri dari limbah padat, cair dan gas. Menurut Peraturan
Menteri Lingkungan Hidup dan Kehutanan No 56 Tahun 2015 limbah yang dihasilkan pelayanan kesehehatan seperti jarum suntik, bekas kasa, bekas perban, kaca preparat, kapas bekas, hasil pemeriksaan laboratorium, dan botol bekas (Peraturan Menteri Lingkungan Hidup No 56 Tahun 2015).

Limbah medis padat yang diproduksi di FKTP dari berbagai ruangan seperti ruang tindakan, ruang gigi, laboratorium, ruang $\mathrm{KB}$, dan ruang farmasi relatif lebih sedikit dibandingkan fasilitas kesehatan tingkat kedua dan ketiga. Namun, jika tidak dikelola dengan benar, limbah yang dihasilkan juga dapat menimbulkan dampak dan masalah yang serius bagi lingkungan dan masyarakat. Pengelolaan limbah medis padat menjadi masalah yang serius karena sangat berpotensi menyebarkan penyakit menular melalui kontak langsung atau tidak langsung dengan media lingkungan. Oleh karena itu, limbah medis padat harus diolah dengan benar, sebelum dibuang ke media lingkungan, agar tidak menimbulkan risiko bagi lingkungan dan masyarakat.

Peran pemimpin dalam meningkatkan kinerja pegawai/karyawan salah satu kunci suskses bagi keberhasilan seluruh organisasi. Dukungan positif pemimpin atau manajemen akan menciptakan lingkungan kerja yang kondusif, dan pemimpin atau manajemen harus memiliki kemampuan untuk memahami karakteristik semua karyawan. Setelah memahami tugas yang diberikan dan memahami karakteristiknya, maka pimpinan atau manajemen akan mampu memberikan arahan, dorongan dan motivasi kepada seluruh karyawan untuk meningkatkan kinerjanya (Lusdiyanti, 2011).

Sejauh ini pengelolaan limbah medis di Fasilitas Pelayanan Kesehatan Tingkat Pertama (FKTP) dilihat dari sikap dan pengetahuan petugas pengelola limbah medis tergolong masih rendah terlihat dari berbagai macam kasus di lapangan dari penyimpanan limbah medis tidak pada tempatnya, penumpukan limbah di fasilitas kesehatan, tempat penyimpanan sementara yang tidak sesuai standar, tidak ada pelabelan pada wadah limbah, berbagai keterbatasan tersebut memicu pengelolaan limbah medis yang belum sesuai standar yang telah ditetapkan. Kemudian dalam 
pengelolaan limbah medis padat membutuhkan biaya yang cukup besar seperti kebutuhan sarana prasarana dalam pengelolaannya.

Tujuan penelitian ini adalah untuk menganalisis pengelolaan limbah medis padat di Fasilitas Pelayanan Kesehatan Tingkat Pertama Kota Padang berdasarkan Peraturan Menteri Lingkungan Hidup dan Kehutanan No 56 Tahun 2015 serta mengetahui pengaruh tingkat pengetahuan, sikap dan dukungan pimpinan terhadap pengelolaan limbah medis padat di Fasilitas Pelayanan Kesehatan Tingkat Pertama Kota Padang.

\section{METODE PENELITIAN}

Penelitian ini dilaksanakan selama bulan Februari sampai Mei tahun 2020. Penelitian ini dilaksanakan di Fasilitas Kesehatan Tingkat Pertama (FKTP) Kota Padang. Metode penelitian ini mengguna-kan pendekatan kuantitatif menekankan analisis pada data-data numerik yang diolah dengan metoda statistik. Sampel pada penelitian ini terdiri dari Puskesmas, Klinik dan Praktek dokter gigi. Pemilihan sampel dengan cluster sampling kemudian menggunakan primary sample unit. Responden dalam penelitian ini adalah petugas pengelola limbah medis padat. Petugas pengelola limbah medis padat di FKTP adalah karyawan atau staf di lingkungan FKTP yaitu cleaning service dan asisten pribadi pada praktek dokter gigi.

Teknik pengumpulan data dengan studi literatur, observasi, wawancara dengan pembagian kuesioner mengenai pengetahuan, sikap dan dukungan pimpinan. Analisis data untuk evaluasi pengelolaan limbah medis padat dengan skala guttman. Sedangkan analisis pengetahuan menggunakan skala Guttman, sikap dan dukungan pimpinan menggunakan skala likert. Kemudian analisis pengetahuan, sikap dan dukungan pimpinan terhadap pengelolaan limbah medis padat menggunakan analisis regresi berganda.

\section{HASIL DAN PEMBAHASAN}

Berdasarkan Peraturan Menteri Lingkungan Hidup dan Kehutanan No 56 Tahun 2015 Tentang Pengelolaan Limbah Medis Padat di Fasilitas Pelayanan Kesehatan bahwa Limbah medis merupakan limbah yang berasal dari rumah fasilitas kesehatan sebagai upaya pelayan kesehatan masyarakat. Pengelolaan limbah medis padat terdiri dari beberapa tahapan yaitu pengumpulan dan pemilahan, penyimpanan, pengangkutan, pemusnahan dan penimbunan. Pada fasilitas pelayanan kesehatan tingkat pertama dimulai dari pengumpulan, dan pemilahan, pengangkutan onsite, penyimpanan, pemantauan, pengelolaan lanjutan dan housekeeping serta SOP. Berikut tahapan pengelolaan limbah medis padat di FKTP Kota Padang.

Berdasarkan hasil analisis data didapatkan persentase pelaksanaan tahapan pemilahan dan pengumpulan limbah medis di FKTP sebesar $81,2 \%$, artinya pengelolaan limbah medis padat dikategorikan sudah sangat baik. Fasilitas Pelayanan Kesehatan Tingkat Pertama (FKTP) telah melakukan pemilahan dan pengumpulan limbah dengan baik yaitu telah melakukan pemilahan sampah medis dan non medis, kemudian penggunaan logo atau pelabelan namun masih ada FKTP yang belum menggunakan logo/pelabelan terhadap wadah limbah medis.

Tahapan pemilahan dan pengangkutan dimulai dari penghasil limbah, dari setiap ruangan di FKTP limbah yang dihasilkan dipilah antara limbah medis dan non medis. Untuk limbah medis kantong yang digunakan berwarna kuning untuk infkesius sedangkan untuk limbah non medis biasanya menggunkan kantong berwarna hitam. Berdasarkan hasil analisis data didapatkan persentase pelaksanaan tahapan pemilahan dan pengumpulan limbah medis di FKTP sebesar $81,2 \%$, artinya pengelolaan limbah medis padat dikategorikan sudah sangat baik.

Fasilitas Pelayanan Kesehatan Tingkat Pertama (FKTP) telah melakukan pemilahan dan pengumpulan limbah dengan baik yaitu telah melakukan pemilahan sampah medis dan non medis, kemudian penggunaan logo atau pelabelan namun masih ada FKTP yang belum menggunakan logo/pelabelan terhadap wadah limbah medis ini sejalan dengan penelitian, pada fasilitas kesehatan ditemukan tidak ada pelabelan terhadap wadah limbah medis. Pelabelan di wadah limbah medis digunakan untuk mengidentifikasi jenis limbah yang kumpulkan di wadah sehingga tidak bercampur dengan limbah non medis (Putri dkk., 2018). 


\section{Persentase Kesesuaian dan Ketidaksesuaian pada Indikator Tahapan Pemilahan dan Pengumpulan Limbah Medis Padat}

Tabel 1. Persentase Kesesuaian dan Ketidaksesuaian pada Indikator Tahapan Pemilahan dan Pengumpulan Limbah Medis Padat

\begin{tabular}{|c|c|c|c|c|c|}
\hline \multirow{2}{*}{ No. } & \multirow{2}{*}{ Ketentuan } & \multicolumn{2}{|c|}{ Sesuai } & \multicolumn{2}{|c|}{ Tidak Sesuai } \\
\hline & & Jumlah & (\%) & Jumlah & $(\%)$ \\
\hline 1. & $\begin{array}{l}\text { Bahan tempat sampah yang digunakan tahan } \\
\text { karat, kedap air, kuat. }\end{array}$ & 58 & 100 & 0 & 0 \\
\hline 2. & $\begin{array}{l}\text { Setiap sampah medis menggunakan logo sesuai } \\
\text { dengan jenis limbah yang dihasilkan }\end{array}$ & 42 & 72,4 & 16 & 27,6 \\
\hline 3. & $\begin{array}{l}\text { Menggunakan safety box untuk benda tajam } \\
\text { sesuai dengan peraturan yang ditetapkan }\end{array}$ & 58 & 100 & 0 & 0 \\
\hline 4. & $\begin{array}{l}\text { Kantong plastik yang digunakan sesuai dengan } \\
\text { jenis limbah yang dihasilkan dan sesuai dengan } \\
\text { peraturan perundangan }\end{array}$ & 50 & 86,2 & 8 & 13,8 \\
\hline 5. & $\begin{array}{l}\text { Dibedakan antara tempat sampah medis dan } \\
\text { non medis }\end{array}$ & 58 & 100 & 0 & 0 \\
\hline 6. & $\begin{array}{l}\text { kantong plastik diangkut apabila sudah terisi } \\
\text { 3/4 bagian }\end{array}$ & 39 & 67,2 & 19 & 32,8 \\
\hline 7. & $\begin{array}{l}\text { Setelah digunakan tempat sampah dibersihkan } \\
\text { dan didesinfeksi }\end{array}$ & 18 & 31,0 & 40 & 69 \\
\hline 8. & $\begin{array}{l}\text { Kantong plastik yang digunakan diganti setiap } \\
\text { hari }\end{array}$ & 54 & 93,1 & 4 & 6,9 \\
\hline
\end{tabular}

Amrullah menyebutkan berdasarkan wawancara dengan salah satu petugas pengelola limbah medis tidak ada pelabelan maupun simbol/ logo atau lambang yang digunakan pada kemasan. Hal ini menjadi penting dalam pelabelan agar petugas mengetahui secara visual terkait pengkodean limbah medis yang berbahaya (Lusdiyanti, 2011; Amrullah, 2019).

Namun pada observasi di lapangan masih ditemukan ketidaksesuaian pelaksanaan pada tahapan pemilahan seperti lapangan petugas pengelola limbah medis padat tidak membersihkan dan mendesinfeksi wadah limbah medis, jika sudah kotor dibersihkan dengan air mengalir. Ini sejalan dengan penelitian Amrullah mengenai pengelolaan limbah medis padat tidak dilakukan desinfeksi terhadap tempat sampah yang telah dikosongkan. Penelitian Yahar pada salah satu fasilitas kesehatan menemukan tempat sampah yang telah digunakan untuk pengumpulan limbah medis padat, karena tempat sampah limbah medis yang tidak dibersihkan dapat menjadi sarang kuman dan vektor penularan penyakit (Amrullah, 2019).

\section{Pengangkutan Onsite}

Tabel 2. Persentase Kesesuaian dan Ketidaksesuaian pada Tahapan Pengangkutan Onsite Limbah Medis Padat

\begin{tabular}{|c|c|c|c|c|c|}
\hline \multirow{2}{*}{ No. } & \multirow{2}{*}{ Ketentuan } & \multicolumn{2}{|c|}{ Sesuai } & \multicolumn{2}{|c|}{ Tidak Sesuai } \\
\hline & & Jumlah & $(\%)$ & Jumlah & $(\%)$ \\
\hline 1. & Menggunakan trolley tertutup atau sejenisnya & 20 & 34,5 & 38 & 65,5 \\
\hline 2. & $\begin{array}{l}\text { Penggunaan alat angkut tidak merusak } \\
\text { kantong pembungkus }\end{array}$ & 19 & 32,8 & 39 & 67,2 \\
\hline 3. & $\begin{array}{l}\text { Setelah digunakan alat angkut dibersihkan dan } \\
\text { di desinfeksi }\end{array}$ & 13 & 22,4 & 45 & 77,6 \\
\hline & & & & & \\
\hline
\end{tabular}


Berdasarkan Tabel 2 mengenai persentase kesesuaian dan ketidaksesuaian pada Tahapan Pengangkutan onsite pengelolaan limbah medis padat di Fasilitas Kesehatan Tingkat Pertama (FKTP) Kota Padang yang terdiri dari 3 indikator terdapat $29,9 \%$ yang sudah memenuhi standar kesesuaian dengan kategori kurang baik. Pengangkutan limbah medis padat dimulai dari titik awal pengumpulan setiap ruangan seperti ruang tindakan, laboratorium, ruang gigi dan lain-lain setelah dikumpulkan limbah medis tersebut diangkut ke tempat penampungan sementara. Berdasarkan analisis data didapatkan persentase pengangkutan onsite sebesar 29,9\% yang sudah memenuhi standar kesesuaian dengan kategori kurang baik. Berdasarkan hasil wawancara dengan salah satu petugas untuk pengangkutan onsite masih menggunakan cara manual yaitu menggunakan tangan dengan kantong plastiknya.

Hal ini sejalan dengan penelitian Pratiwi dan Chatila yang berpendapat bahwa proses pengangkutan limbah medis padat di beberapa FKTP tidak menggunakan alat angkut, hanya manual saja kantong yang berisi limbah tersebut dibawa dengan tangan tanpa alat angkut (Maharani, 2013).

Petugas pengelola limbah medis padat alat angkut yang digunakan jarang dibersihkan, kalau dibersihkan hanya menggunakan air mengalir tanpa desinfeksi. Penelitian Salam menyebutkan wadah atau alat angkut yang telah digunakan untuk pengangkutan limbah medis harus segera dibersihkan dengan desinfektan jika digunakan kembali (Salam, 2013). Peraturan Menteri Lingkungan Hidup dan Kehutanan No 56 Tahun 2015 mengenai Tatacara Pengelolaan Limbah B3 Fasilitas Pelayanan Kesehatan bahwa alah angkut yang telah digunakan harus dilakukan pembersihan dan desinfeksi setiap hari dengan menggunakan senyawa klorin, formaldehidra, fenolik dan asam (Peraturan Menteri Lingkungan Hidup No 56 Tahun 2015).

\section{Tempat Penampungan Sementara}

Tabel 3. Persentase Kesesuaian dan Ketidaksesuaian pada Tempat Penampunagan Sementara Limbah Medis Padat

\begin{tabular}{|c|c|c|c|c|c|}
\hline \multirow{2}{*}{ No. } & \multirow{2}{*}{ Ketentuan } & \multicolumn{2}{|c|}{ Sesuai } & \multicolumn{2}{|c|}{ Tidak Sesuai } \\
\hline & & Jumlah & $(\%)$ & Jumlah & $(\%)$ \\
\hline 1. & $\begin{array}{l}\text { Memiliki tempah khusus } \text { penyimpanan } \\
\text { sementara limbah medis }\end{array}$ & 23 & 39,7 & 35 & 60,3 \\
\hline 2. & $\begin{array}{l}\text { Penyimpanan limbah medis maksimal } 2 \times 24 \\
\text { jam }\end{array}$ & 6 & 10,3 & 52 & 89,7 \\
\hline 3. & $\begin{array}{l}\text { Apabila melebihi } 2 \times 24 \text { jam menggunakan } \\
\text { cold storage }\end{array}$ & 6 & 10,3 & 52 & 89,7 \\
\hline 4. & Tersedia sumber air bersih/kran & 11 & 19 & 47 & 81 \\
\hline 5 . & $\begin{array}{l}\text { Dilengkapi ventilasi dan pencahayaan yang } \\
\text { baik }\end{array}$ & 23 & 39,7 & 35 & 60,3 \\
\hline 6. & $\begin{array}{l}\text { Lantai kedap, berlantai beton atau semen } \\
\text { dengan drainase yang baik }\end{array}$ & 23 & 39,7 & 35 & 60,3 \\
\hline 7. & $\begin{array}{l}\text { Tersedia wadah atau kantong limbah } \\
\text { diletakkan sedekat mungkin dengan TPS }\end{array}$ & 20 & 34,5 & 38 & 65,5 \\
\hline 8. & APD yang digunakan sepatu boot & 21 & 34,5 & 37 & 63,8 \\
\hline 9. & APD yang digunakan masker & 28 & 48,3 & 30 & 51,7 \\
\hline 10. & $\begin{array}{l}\text { APD yang digunakan handscoon (sarung } \\
\text { tangan) }\end{array}$ & 44 & 75,9 & 14 & 24,1 \\
\hline 11. & APD yang digunakan baju pelindung & 22 & 37,9 & 36 & 62,1 \\
\hline \multirow[t]{2}{*}{12.} & Tersedia peralatan pembersihan & 23 & 39,7 & 35 & 60,3 \\
\hline & & \multicolumn{2}{|c|}{$36 \%$} & \multicolumn{2}{|c|}{$4 \%$} \\
\hline
\end{tabular}


Berdasarkan Tabel 3 mengenai persentase tahapan pemantauan pengelolaan limbah medis padat di FKTP kota Padang secara umum telah dilaksanakan sesuai dengan peraturan yang ditetapkan yaitu sebesar 76\%. Dari 4 indikator tahapan pemantauan sebagain besar sudah memenuhi standar acuan yang telah ditetapkan. Kecuali 1 indikator yang belum memenuhi standar yaitu Izin Tempat Penampungan Sementara (TPS) LB3 hanya 39,7\% yang memenuhi standar.

Limbah medis yang berasal dari setiap ruangan di Fasilitas Kesehatan Tingkat Pertama (FKTP) ditampung pada tempat penampungan sementara sebelum akhirnya dimusnahkan atau menggunakan jasa pihak ketiga untuk pemusnahan. Limbah medis tersebut ditampung atau dikemas dalam kantong pelapis plastik yang terikat. Lokasi atau area tempat penampungan sementara sampah dapat dikunci untuk mencegah masuknya orang-orang yang tidak berke-pentingan. Limbah medis yang ada di tempat penampungan sementara dikemas menggu-nakan kantong pelapis plastik sebelum akhirnya diangkut oleh kendaraan pengangkut.

Berdasarkan persentase kesesuaian dan ketidaksesuaian tahapan pada Tempat Penampungan Sementara menunjukkan 36\% yang memenuhi standar kesesuaian sehingga dikategorikan pengelolaan limbah medis padat Tempat Penampungan Sementara kurang baik. Observasi di lapangan tempat penyimpanan sementara untuk limbah medis menggunakan box atau wadah tertentu yang belum memenuhi standar acuan yang telah ditetapkan, tempat penyimpanan tersebut mudah dijangkau anakanak serta tidak ada pengunci dan label limbah B3. Hasil wawancara dengan salah satu petugas pengelola limbah medis di Praktek Dokter Gigi mereka hanya menggunakan wadah tertutup seperti box dan tidak memiliki tempat khusus untuk penyimpanan limbah, dikarenakan limbah yang dihasilkan relative sedikit. Sedangkan untuk Puskesmas dan Klinik sudah memiliki Tempat Penampungan Sementara khusus limbah medis padat. Namun kendala yang dihadapi seperti pemeliharaan TPS masih belum terjaga dengan baik.

Dalam pengelolaan limbah medis padat setiap pekerja harus menggunakan Alat Pelindung (APD). Peraturan Menteri Lingkungan Hidup dan Kehutanan No 56 Tahun 2015 tentang Tatacara Pengelolaan
Limbah B3 di Fasilitas pelayanan Kesehatan didapatkan setiap petugas pengelola limbah medis harus menggunakan Alat Pelindung Diri (APD) dan harus memperhatikan hygiene perorangan untuk mengurangi resiko dari pengelolaan limbah medis pelayanan kesehatan karena dapat menimbulkan gangguan kesehatan bagi petugas pengelola limbah medis padat apabila tidak menggunakan APD. APD yang digunakan adalah sarung tangan, masker, celana panjang, sepatu boot, celemek, dan baju lengan panjang (Peraturan Menteri Lingkungan Hidup No 56 Tahun 2015).

APD merupakan pakaian pelindung yang digunakan oleh petugas pengelola limbah medis padat yang bertujuan untuk melindungi petugas dari risiko terinfeksi limbah. Santy dan Cut menyebutkan bahwa petugas pengelola limbah medis memiliki risiko tinggi terhadap infeksi nosokomial, dikarenakan bersentuhan langsung pada proses pengumpulan dan pengelolaan limbah tersebut (Purba, 2018). Berdasarkan wawancara dengan beberapa petugas pengelola limbah medis padat mereka hanya menggunakan masker dan sepatu tertutup/ sendal dan kadang-kadang menggunakan sarung tangan. Diakui oleh petugas tersebut mereka memang memerlukan APD dalam melakukan pengelolaan limbah medis padat namun terkadang kurang nyaman dengan penggunaannya serta masih minimnya ketersediaan APD. Ini sejalan dengan penelitian Amrullah bahwa petugas kurang nyaman menggunakan APD sehingga mereka hanya menggunakan masker atau sarung tangan saja (Amrullah.,2019), disisi lain petugas tersebut menyebutkan bahwa APD diperlukan untuk perlindungan. Penelitian kesadaran petugas pengelola limbah medis padat penggunaan APD masih rendah $(52,4 \%)$ disebabkan juga karena kurangnya sosialisasi tentang penggunaan APD (Purba, 2018).

\section{Hubungan Tingkat Pengetahuan, Sikap dan Persepsi Dukungan Pimpinan Petugas terhadap Pengelolaan Limbah Medis Padat di Fasilitas Kesehatan Tingkat Pertama (FKTP) Kota Padang}

Pada penelitian ini analisis yang digunakan adalah regresi berganda dimulai dari uji asumsi klasik kemudian dilakukan uji regresi berganda, sehingga didapatkan hasil sebagai berikut: 
Tabel 4. Hasil Perhitungan Uji t

\begin{tabular}{lccccc}
\hline \multirow{2}{*}{ Model } & \multicolumn{2}{c}{$\begin{array}{c}\text { Unstandardized } \\
\text { Coefficients }\end{array}$} & $\begin{array}{c}\text { Standardized } \\
\text { Coefficients }\end{array}$ & $\mathrm{t}$ & Sig. \\
\cline { 2 - 6 } & $\mathrm{B}$ & Std. Error & Beta & & \\
\hline (Constant) & $-10,771$ & 3,591 & & $-2,999$ & 0,004 \\
Pengetahuan & 0,327 & 0,148 & 0,193 & 2,213 & 0,031 \\
Sikap & 0,326 & 0,115 & 0,259 & 2,829 & 0,007 \\
Dukungan Pimpinan & 0,403 & 0,068 & 0,549 & 5,952 & 0,000 \\
\hline
\end{tabular}

Persamaan regresi yang bisa dibentuk adalah sebagai berikut:

$\mathrm{Y}=-10,771+0,327 \mathrm{X} 1+0,326 \mathrm{X} 2+0,403$ $\mathrm{X} 3+\mathrm{e}$

Persamaan ini dapat diinterprestasikan sebagai berikut:

Konstanta (a): $-10,771$, nilai konstanta bernilai negatif artinya jika skor variabel pengetahuan, sikap dan dukungan pimpinan dianggap tidak ada atau nol, maka skor pengelolaan limbah medis padat akan semakin berkurang.

Koefisien b1: 0,327, koefisien variabel tingkat pengetahuan bernilai positif artinya tingkat pengetahuan berpengaruh nyata dan bernilai positif terhadap pengelolaan limbah medis padat. Jika skor tingkat pengetahuan meningkat maka pengelolaan limbah medis padat semakin tinggi atau baik.

Koefisien b2: 0,326 koefisien variabel sikap bernilai positif artinya sikap berpengaruh nyata dan bernilai positif terhadap pengelolaan limbah medis padat. Jika skor sikap meningkat maka skor pengelolaan limbah medis padat semakin tinggi atau baik.

Koefisien b3: 0,403, koefisien variabel dukungan pimpinan bernilai positif artinya dukungan pimpinan berpengaruh nyata dan bernilai positif terhadap pengelolaan limbah medis padat. Jika skor dukungan pimpinan meningkat maka skor pengelolaan limbah medis padat semakin tinggi atau baik.

Dari tabel 4, dapat diketahui hasil analisis regresi sebagai berikut:

\section{Hubungan Tingkat Pengetahuan Petugas dengan Pengelolaan Limbah Medis Padat}

Hasil uji pengaruh antara tingkat pengetahuan dengan pengelolaan limbah medis padat menunjukkan p-value (sig) sebesar 0,031 dibawah alpha 5\%. Artinya bahwa pengetahuan berpengaruh nyata terhadap pengelolaan limbah padat di FKTP Kota Padang.

\section{Hubungan Sikap Petugas dengan Pengelolaan Limbah Medis Padat}

Hasil uji pengaruh antara sikap responden dengan pengelolaan limbah medis padat menunjukkan p-value (sig) sebesar 0.007 dibawah alpha 5\% artinya bahwa sikap berpengaruh nyata terhadap pengelolaan limbah padat di FKTP Kota Padang.

\section{Hubungan Persepsi Dukungan Pimpinan dengan Pengelolaan Limbah Medis Padat}

Hasil uji pengaruh antara dukungan pimpinan dengan pengelolaan limbah medis padat menunjukkan nilai t hitung 5,952 dan p-value (sig) sebesar 0.000 dibawah alpha 5\%. Artinya bahwa dukungan pimpinan berpengaruh nyata terhadap pengelolaan limbah padat di FKTP Kota Padang.

Pengaruh Tingkat Pengetahuan, Sikap Petugas Pengelola Limbah serta Dukungan Pimpinan Terhadap Pengelolaan Limbah Medis Padat di FKTP Kota Padang

\section{Pengaruh Tingkat Pengetahuan Petugas Pengelola Limbah Medis Padat}

Hasil uji pengaruh antara tingkat pengetahuan dengan pengelolaan limbah medis padat menunjukkan p-value (sig) sebesar 0,031 dibawah alpha 5\%. Artinya bahwa pengetahuan berpengaruh nyata terhadap pengelolaan limbah padat di FKTP Kota Padang. Penelitian ini sejalan dengan penelitian bahwa pengetahuan petugas berpengaruh terhadap pengelolaan limbah medis padat di FKTP, dengan hasil penelitian pengetahuan petugas masih tergolong rendah (Nursamsi dkk., 2017). Tindakan berdasarkan pengetahuan dan kesadaran berlangsung lebih 
lama daripada tindakan yang tidak didasari pengetahuan dan kesadaran (Widiartha, 2012). Tinggi rendahnya tingkat pengetahuan responden disebabkan banyaknya informasi yang diperoleh oleh petugas pengelola limbah medis, semakin tinggi informasi yang diperoleh petugas pengelola limbah medis maka semakin tinggi pula tingkat pengetahuannya. Semakin sedikit informasi yang diperoleh semakin rendah pula pengetahuan petugas terhadap pengelolaan limbah medis padat.

Salah satu petugas pengelola limbah medis menyebutkan bahwa mereka belum pernah mendapatkan penyuluhan atau sosialisasi mengenai pengelolaan limbah medis ini dan mereka hanya mengetahui dari karyawan yang lain serta melihat cara kerja petugas pengelola limbah medis lainnya. Dari hal diatas didapatkan bahwa kurangnya pengetahuan petugas pengelola limbah medis disebabkan masih minimnya penyuluhan atau sosialisasi yang dilakukan oleh pihak Fasilitas Kesehatan Tingkat Pertama dan juga masih minimnya media informasi yang didapatkan petugas pengelola limbah medis seperti poster, leaflet, dan buku ataupun melalui media suara ke seluruh ruangan Fasilitas Kesehatan Tingkat Pertama.

Pengetahuan bagi petugas pengelola limbah medis sangat diperlukan untuk menjadi acuan dan pedoman dalam melaksanakan tugasnya, karena limbah medis yang dihasilkan tidak hanya berisiko bagi petugas saja, tetapi seluruh yang berada di FKTP dan juga beresiko terhadap lingkungan dapat melalui pelatihan atau penyuluhan. Upaya untuk meningkatkan pengetahuan petugas dengan memberikan pelatihan dan sosialisasi sebagai bentuk meningkatkan wawasan dan pengetahuan bagi petugas dalam pengelolaan limbah medis padat untuk mengurangi dampak terjadinya infeksi nosokomial dan lingkungan.

Salah satu faktor eksternal untuk mengetahui tingkat pengetahuan adalah berdasarkan usia. Semakin lama mereka berhubungan dengan pengelolaan limbah medis semakin banyak pengalaman yang di dapatkan sehingga meningkatkan pengetahuan petugas tersebut. Pengetahuan yang baik ini memungkinkan mereka untuk bekerja dengan baik dalam kesehatan dan keselamatan kerja. Oleh karena itu, mereka harus berhatihati dan cenderung mengikuti prosedur keselamatan yang ditetapkan di tempat kerja. Dengan cara ini, resiko dapat berkurang. Namun, jika jam kerja petugas pendek, biasanya petugas kurang berhati-hati dan tergesa-gesa. Hal ini dikarenakan mereka masih belum mengetahui risiko bahaya yang ada di tempat kerja mereka. Kemungkinan mereka terkena risiko bahaya di tempat kerja tersebut semakin besar.

Dalam upaya meningkatkan kualitas lingkungan, dalam hal ini pendidikan berperan penting dalam pencegahan pencemaran lingkungan dengan cara mengelola limbah medis baik dan benar. Tingkat pendidikan seseorang juga berperan dalam menentukan dan menerima pembaruan apa pun dan memengaruhi proses pembelajaran. Oleh karena itu, melalui edukasi, tenaga pengelola limbah medis dapat lebih mudah memperoleh informasi dan pengetahuan terkait pengelolaan limbah medis, khususnya bahaya pencemaran bagi lingkungan dan kesehatan manusia. Memberikan edukasi lingkungan kepada petugas pengelolaan limbah medis, khususnya pengetahuan terkait pengelolaan limbah medis untuk lingkungan dan keselamatan manusia, serta mengenalkan kepada mereka bagaimana cara mengelola limbah medis secara benar tanpa merugikan lingkungan serta bahaya apa yang ditimbulkan baik bagi petugas yang mengelola, karyawan, pengunjung dan masyarakat sekitar Fasilitas Kesehatan Tingkat Pertama.

\section{Pengaruh Sikap Petugas Pengelola Limbah Medis Padat}

Hasil uji pengaruh antara sikap responden dengan pengelolaan limbah medis padat menunjukkan p-value (sig) sebesar 0,007 dibawah alpha 5\% artinya bahwa sikap berpengaruh nyata terhadap pengelolaan limbah padat di FKTP Kota Padang. Sikap bukan hanya menyangkut sangat setuju, setuju, ragu-ragu, tidak setuju dan sangat tidak setuju saja, namun juga menyangkut hasil akhir dari pelaksanaan pengelolaan limbah medis padat. Faktor yang mempengaruhi pembentukan sikap seseorang diantaranya adalah pengalaman pribadi dan orang lain yang dianggap penting. Berdasarkan wawancara dengan salah satu petugas pengelola limbah medis padat mereka melakukan pemilahan hingga pengangkutan oleh pihak ketiga dilakukan dengan melihat dan bertanya kepada teman- 
teman yang lain, karena ketika mereka menjadi petugas hanya diberitahu tempat sampah yang digunakan dan tempat pembuangan limbah medis tersebut (Sudiharti, 2013).

Hasil penelitian ini sejalan dengan Zuchdi, dkk menyatakan Sikap positif dan netral, karena responden hanya menjawab halhal yang baik saat menjawab pernyataan, karena sikap tersebut merupakan respon tertutup dan tidak muncul dalam situasi sebenarnya, sehingga meskipun pengelola setuju pengelolaan limbah medis belum tentu bertindak sesuai dengan sikapnya sendiri. Sikap yang tidak sesuai dengan perilaku bergantung pada lingkungan dan kondisi. Sikap untuk melakukan suatu kegiatan menjadi tindakan apabila mendapat dukungan sosial dari lingkungannya. Sikap tidak dapat terjadi begitu saja tanpa ada pengaruh dari orang sekitar. Dalam hal ini dimungkinkan pimpinan yang berpengaruh terhadap tugas dan tanggung jawab petugas pengelola limbah medis sehingga membentuk suatu karakter petugas dengan memotivasi sehingga tidak hanya sikap setuju saja namun selaras juga dengan pelaksanaan pengelolaan limbah medis yang baik dan benar (Zuchdi, 1995).

\section{Pengaruh Dukungan Pimpinan}

Hasil uji pengaruh antara dukungan pimpinan dengan pengelolaan limbah medis padat menunjukkan p-value (sig) sebesar 0.000 dibawah alpha 5\%. Artinya bahwa dukungan pimpinan berpengaruh nyata terhadap pengelolaan limbah padat di FKTP Kota Padang. Dukungan pimpinan dapat dilihat dari seorang pimpinan dalam mengarahkan, mendorong, dan mengatur seluruh unsur-unsur di dalam kelompok untuk mencapai tujuan sehingga tercapainya hasil kerja karyawan dalam mewujudkan tujuan dalam pengelolaan limbah medis padat yaitu melindungi pasien, petugas kesehatan, pengunjung dan masyarakat sekitar dari penyebaran infeksi dan cidera serta mencegah dan menanggulangi pencemaran atau kerusakan lingkungan .

Karyawan dan pimpinan mempunyai konstribusi besar terhadap berjalannya institusi kesehatan, oleh karena itu pimpinan harus bisa menemptakan perannya sebagai kepala di semua bidang sehingga dapat mengatur karyawan agar bekerja dengan baik dan memotivasi karyawan. Peran pimpinan dalam pengelolaan limbah medis padat, menerapkan kebijakan dan peraturan yang telah ada seperti Peraturan Lingkungan Hidup No 56 Tahun 2015 mengenai pengelolaan limbah medis padat, pengawasan tidak hanya penanggung jawab limbah medis tetapi juga dari pimpinan, pelaksanaan pengelolaan limbah medis padat berjalan sesuai dengan kebijakan yang ada ketika pimpinan dapat memberikan pengaruh terhadap seluruh karyawan seperti memberikan teguran atau sanksi kepada petugas yang masih kurang memperhatikan pengelolaan limbah medis, dalam pelaksanaan pengelolaan limbah medis padat seperti kendala yang ditemukan dilapangan, cairan desinfeksi. Dukungan pimpinan yang positif dapat memberikan contoh perilaku agar karyawan mau bekerja sama dan bekerja secara efektif dan efisien untuk mencapai tujuan (Peraturan Menteri Lingkungan Hidup No 56 Tahun 2015).

Dari penelitian ini didapatkan dukungan pimpinan masih tergolong belum sering sehingga harus adanya dorongan dan motivasi dari pimpinan terkait pelaksanaan pengelolaan limbah medis padat ini. Sehingga upaya peningkatan dukungan pimpinan menjadi sangat penting dilakukan. Notoatmojo mendefinisikan motivasi sebagai interaksi antara perilaku dengan lingkungan sehingga perilaku dapat ditingkatkan, diturunkan, atau dipertahankan. Untuk meningkatkan pelayanan kesehatan dan pengelolaan limbah medis yang benar dan sesuai aturan yang ditetapkan agar dapat bertahan maka meningkatkan kinerja karyawan dengan meningkatkan dukungan pimpinan, karena dukungan pimpinan dalam fasilitas kesehatan merupakan faktor pendorong dan pendukung dalam memimpin karyawan untuk meningkatkan kinerjanya (Notoatmodjo, 2012).

Dukungan pimpinan terhadap pengelolaan limbah medis padat sangat diperlukan dalam hal ini dapat berupa bimbingan, pengawasan secara langsung, atau reward terhadap pengelolaan limbah medis sehingga petugas termotivasi, misalnya dengan kelengkapan petugas dalam penggunaan Alat Pelindung Diri (APD) diberikan penghargaan berupa sertifikat kepatuhan pelaksanaan kesehatan dan keselamatan kerja. Menurut dukungan pimpinan dapat berupa bimbingan dengan metode on the job training merupakan 
proses yang terorganisasi untuk meningkatkan keterampilan, pengetahuan, kebiasaan kerja, dan sikap pekerja. Artinya pelatihan bagi petugas pengelola limbah medis padat dilakukan dengan cara petugas ditempatkan pada kondisi sebenarnya dibawah bimbingan dan pengawasan (Leolin ,2019; Andani, 2018).

\section{KESIMPULAN DAN SARAN}

Analisis pengelolaan limbah medis padat di Fasilitas Kesehatan Tingkat Pertama (FKTP) yaitu Puskesmas dan Klinik sebagian besar sudah memenuhi standar kesesuaian berdasarkan Peraturan Menteri Lingkungan Hidup dan Kehutanan No 56 Tahun 2015 mengenai Tatacara Pengelolaan Limbah Medis di Fasilitas Pelayanan Kesehatan, namun untuk Praktek Dokter gigi masih tergolong rendah. Pengaruh tingkat pengetahuan, sikap dan dukungan pimpinan terhadap pengelolaan limbah medis padat di Fasilitas Kesehatan Tingkat Pertama (FKTP) diketahui berpengaruh nyata terhadap pengelolaan limbah medis padat.

Diharapkan untuk seluruh FKTP mempunyai komitmen dan mengurus izin pelaksanaan pengelolaan limbah medis padat berdasarkan peraturan yang telah ditetapkan, secara tertulis dan diawasi langsung oleh Dinas Kesehatan Kota, adanya pelatihan dan sosialisasi secara berkala kepada seluruh staf FKTP mengenai pengelolaan limbah medis padat sesuai ketentuan yang berlaku, dan adanya dukungan pimpinan secara total terhadap pengelolaan limbah medis padat dengan berpedoman pada peraturan dan kebijakan yang telah berlaku.

\section{REFERENSI}

Amrullah, Amrullah Aam. (2019). "Analisis Pengelolaan Limbah Medis Puskesmas Di Kecamatan Babulu Kabupaten Penajam Paser Utara Berdasarkan Permenkes Nomor 27 Tahun 2017." Husada Mahakam: Jurnal Kesehatan 4(8):453.

Andani, Rosihan. (2018). Pengelolaan Limbah Medis Pelayanan Kesehatan. Banjarmasin: Lambung Mangkurat
Press.

Leolin. (2019). "Analisis Sistem Pengelolaan Limbah B3 Puskesmas Kota Padang." Universitas Andalas.

Lusdiyanti, Evi Siwi. (2011). “Analisis Pengaruh Dukungan Pimpinan Dan Dukungan Organisasi Pada Kinerja Dan Komitmen Afektif Karyawan Pt Inka Madiun." Riset Manajemen Dan Akuntansi 2(3):138-59.

Maharani, Dyah Pratiwi dan Chatila. (2013). "Pengelolaan Limbah Medis Padat Pada Puskesmas Kabupaten Pati." KESMAS - Jurnal Kesehatan Masyarakat 9(1):74-84.

Notoatmodjo, Soekidjo. (2012). Promosi Kesehatan Dan Perilaku Kesehatan. Jakarta: Rineka Cipta.

Nursamsi, Nursamsi, Thamrin Thamrin, and Deni Efizon. (2017). "Analisis Pengelolaan Limbah Medis Padat Puskesmas Di Kabupaten Siak." Dinamika Lingkungan Indonesia 4(2):86.

Peraturan Menteri Lingkungan Hidup No 56 Tahun 2015. (2015). Tata Cara Dan Persyaratan Teknis Pengelolaan Limbah Bahan Berbahaya Dan Beracun Dari Fasilitas Pelayanan Kesehatan.

Peraturan Pemerintah Nomor 47 Tahun 2016. (2016). "Peraturan Pemerintah Nomor 47 Tahun 2016 Tentang Fasilitas Pelayanan Kesehatan." (101):1-2.

Purba, Elfrida Santy, and Cut Khairunnisa. (2018). "Hubungan Pengetahuan, Sikap Dan Ketersediaan Fasilitas Dengan Praktik Petugas Pengumpul Limbah Medis Di Rumah Sakit Umum Cut Meutia Kabupaten Aceh Utara Tahun 2015." AVERROUS: Jurnal Kedokteran Dan Kesehatan Malikussaleh 1(2):23.

Putri, Dewa Ayu Putu Gek Mega Suryasih, Ni Kd. Fiora Rena Pertiwi, and Ni Made Sri Nopiyani. (2018). "Manajemen Pengelolaan Limbah Medis Di Praktik Dokter Gigi Kabupaten Tabanan.” Bali Dental Journal 2(1):9-16.

Salam, Hadianty. (2013). "Gambaran Pengelolaan Limbah Medis Padat Di Rumah Sakit Dr. Tadjuddin Khalid Kota Makassar." Universitas Islam Negeri Makassar. 
Sudiharti and Solikhah. (2013). "Hubungan Pengetahuan Dan Sikap Dengan Perilaku Perawat Dalam Pembuangan Sampah Medis Di Rumah Sakit PKU Muhammadiyah Yogyakarta." Jurnal Kesehatan Masyarakat (Journal of Public Health) 6(1):49-59.

Undang-Undang Nomor 36 Tahun 2009 Tentang Kesehatan. (2009). UndangUndang Republik Indonesia.
Undang-Undang Republik Indonesia. n.d. Undang-Undang No. 32 Tentang Perlindungan Dan Pengelolaan Lingkungan Hidup.

Widiartha, Komang Yudha. (2012). "Analisis Pengelolaan Limbah Medis Puskesmas Di Kabupaten Jember.” 66:37-39.

Zuchdi, Darmiyati. (1995). "Pembentukan Sikap (Teori Reasoned Action)." Jurnal Cakrawala Pendidikan 3(3):51-63. 